\title{
Analisis Regresi Balanced Panel dengan Komponen Galat Dua Arah pada Kasus Melek Huruf Masyarakat di Provinsi NTB
}

\author{
Muhammad Irwansyah *, Ruliana, \& Muhamad Kasim Aidid \\ Program Studi Statistika, Fakultas Matematika dan Ilmu Pengetahuan Alam, Universitas Negeri Makassar, Indonesia
}

Keywords: regresi data panel, common effect model, fixed effect model, random effect model, melek huruf.

\begin{abstract}
:
Analisis regresi adalah suatu metode untuk melihat pengaruh antara satu atau lebih peubah bebas terhadap peubah terikat. Data yang digunakan untuk analisis regresi ada yang berupa penggabungan antara data cross section dengan data time series yang dikenal dengan nama data panel. Data panel yang memiliki jumlah pengamatan waktu yang sama di setiap objek pada tabulasi silang merupakan data panel lengkap (Balanced panel). Penelitian ini mencari nilai dugaan terhadap model regresi data panel dengan komponen galat dua arah yaitu galat pada waktu dan galat pada individu. Analisis regresi data panel dapat menggunakan tiga pendekatan yaitu common effect model, fixed effect model, dan random effect model. Pemilihan model terbaik dari ketiga pendekatan regresi data panel menggunakan uji hausman, uji chow, dan uji lagrange multipler. Dalam penelitian ini didapatkan model terbaik yaitu model random effect dimana peubah yang memiliki pengaruh signifikan terhadap melek huruf di Provinsi NTB yaitu rasio murid guru tingkat SMP rasio murid guru tingkat SMA, dan persentase penduduk miskin. Model regresi data panel yang terbentuk yaitu: $\hat{Y}=117,5728-0,1967 \mathrm{X}_{5}$ $0,3091 X_{6}-0,3297 X_{7}+\varepsilon$.
\end{abstract}

\section{Pendahuluan}

Analisis regresi adalah suatu metode statistika yang digunakan untuk melihat pengaruh antara peubah yang satu terhadap peubah yang lain. Analisis regresi terbagi menjadi dua yaitu analisis regresi linear sederhana dan analisis regresi linear berganda. Menurut Tiro (2010) analisis regresi sederhana merupakan analisis yang digunakan untuk mengetahui hubungan dari peubah terikat $\mathrm{Y}$ terhadap satu peubah yang lain $\mathrm{X}$, yang disebut peubah bebas.

Penggunaan analisis regresi banyak digunakan di berbagai bidang keilmuan seperti sosial dan pendidikan. Adapun data yang digunakan dalam analisis regresi juga bervariasi, mulai data numerik, kategori, data panel, dan sebagainya.

Menurut Sunengsih (2009), data panel merupakan data gabungan antara data cross section dengan data time series, dimana unit cross section yang sama diukur pada waktu yang berbeda. Maka dengan kata lain, data panel merupakan data dari beberapa individu sama yang diamati dalam kurun waktu tertentu. Jika jumlah unit waktu sama untuk setiap individu, maka data disebut balanced panel. Sebaliknya, jika jumlah unit waktu berbeda untuk setiap individu, maka disebut unbalanced panel.

Data time series biasanya meliputi satu objek tetapi meliputi beberapa periode (bisa harian, bulanan, kuartalan, atau tahunan). Data silang terdiri dari atas beberapa atau banyak objek, sering disebut responden (misalnya perusahaan) dengan beberapa jenis data (misalnya laba, biaya iklan, laba ditahan, dan tingkat investasi) dalam suatu periode waktu

\footnotetext{
* Corresponding author.

E-mail address: irwanmbozho16@gmail.com
} 
tertentu (Pangestika, 2015). Data time series maupun cross section dapat berlaku di berbagai bidang ilmu, baik itu ekonomi, sosial, pendidikan, dan sebagainya.

Angka buta huruf usia 15-59 tahun di Indonesia dilihat dari masing- masing provinsi masih terdapat 11 provinsi memiliki angka buta huruf diatas angka nasional.

Tabel. 1 Angka Buta Huruf Usia 15-59 Tahun 11 Provinsi Diatas Angka Nasional

\begin{tabular}{llc}
\hline No. & \multicolumn{1}{c}{ Provinsi } & Angka buta huruf $(\%)$ \\
\hline 1 & Papua & 28,75 \\
2 & Nusa Tenggara Barat & 7,91 \\
3 & Nusa Tenggara Timur & 5,15 \\
4 & Sulawesi Barat & 4,58 \\
5 & Kalimantan Barat & 4,50 \\
6 & Sulawesi Selatan & 4,49 \\
7 & Bali & 3,57 \\
8 & Jawa Timur & 3,47 \\
9 & Kalimantan Utara & 2,90 \\
10 & Sulawesi Tenggara & 2,74 \\
11 & Jawa Tengah & 2,20 \\
\hline
\end{tabular}

Sumber: Badan Pusat Statistik (BPS) serta Pusat Data dan Statistik Pendidikan dan Kebudayaan Kemendikbud (2017).

Untuk mengetahui faktor-faktor yang berpengaruh terhadap angka melek huruf di NTB dibutuhkan analisis tertentu yang dapat menjelaskan secara luas tentang melek huruf yang nantinya akan menjadi tolak ukur dalam meningkatkan melek huruf di NTB.

Menurut penelitian (Astuti, 2017) "Pemodelan Angka Buta Huruf di Kabupaten/Kota se-Jawa Timur dengan Metode Geographically Weighted t Regression", terdapat beberapa faktor yang telah terbukti memberikan pengaruh yang signifikan terhadap tingkat buta huruf, yang menyimpulkan bahwa Rasio murid-sekolah $\left(\mathrm{X}_{3}\right)$ dan Tingkat Pengangguran Terbuka $\left(\mathrm{X}_{4}\right)$ tidak memenuhi asumsi multikoleniaritas, dan dihilangkan. Sedangkan nilai Zhitung semua peubah prediktor yang lain lebih besar dari 1,64 sehingga diputuskan tolak Ho yang artinya peubah angka partisipasi murni tingkat $\mathrm{SD}\left(\mathrm{X}_{\mathrm{I}}\right)$, rasio murid-guru $\left(\mathrm{X}_{2}\right)$, tingkat pengangguran terbuka $\left(\mathrm{X}_{3}\right)$, persentase penduduk miskin $\left(\mathrm{X}_{4}\right)$ dan persentase balita gizi buruk $\left(\mathrm{X}_{5}\right)$ berpengaruh signifikan terhadap angka buta huruf di Kabupaten/Kota se-Jawa Timur.

\section{Tinjauan Pustaka}

\subsection{Regresi Linear}

Regresi linear merupakan metode statistika yang digunakan untuk melihat pengaruh peubah prediktor terhadap peubah terikat. Menurut Tiro (2010) analisis regresi sederhana merupakan analisis yang digunakan untuk mengetahui hubungan dari peubah terikat $\mathrm{Y}$ terhadap satu peubah yang lain $\mathrm{X}$, yang disebut peubah bebas. Suatu model regresi linear Sederhana dengan k peubah dapat dituliskan dalam bentuk:

$$
Y=\beta_{0}+\beta_{1} X+\varepsilon
$$

di mana $\beta_{0}$ adalah intersep dan $\beta_{1}$ adalah parameter terkait dengan peubah $\mathrm{j}$

Regresi linear berganda merupakan suatu metode statistika yang digunakan untuk melihat pengaruh dua atau lebih peubah bebas terhadap peubah terikat. Secara umum model regresi linear ganda (Ra'yan, 2018) dapat ditulis:

$$
Y=\beta_{1}+\beta_{2} X_{2}+\beta_{3} X_{3}+\cdots+\beta_{k} X_{k}+\varepsilon
$$

dengan :

$\beta_{1} \quad=$ intercept 


$$
\begin{array}{ll}
\beta_{2}, \beta_{3}, \ldots, \beta_{k} & =\text { slope } \\
\varepsilon & =\text { error, } \varepsilon \sim N\left(0, \sigma^{2}\right) \\
\mathrm{k} & =\text { banyaknya pengamatan }
\end{array}
$$

\subsection{Data Panel}

Data cross section merupakan data yang terdiri dari satu atau lebih objek yang dikumpulkan dalam satu waktu. Sedangkan data time series merupakan data yang diamati dan diambil pada waktu berbeda. Data time series memiliki interval waktu yang teratur seperti data harian, bulanan, tahunan (Pangestika, 2015).

Data yang terdiri dari data cross section dan data time series disebut pooled data. Bentuk khusus dari data berbentuk pooled disebut data panel. Data panel didefinisikan sebagai kumpulan pengamatan pada data tabulasi silang yaitu setiap objek yang sama (misalnya keluarga atau perusahaan) diamati dari waktu ke waktu (Jacob, 2014).

Berdasarkan kelengkapan data panel, terdapat dua jenis data panel yaitu data panel seimbang (balanced panel data) dan data panel tidak seimbang (unbalanced panel data). Jika setiap objek memiliki jumlah pengamatan waktu yang sama maka data panel disebut data panel seimbang. Sedangkan jika jumlah pengamatan waktu berbeda pada setiap objek, maka data panel disebut data panel tidak seimbang. Data panel seimbang disebut juga data panel lengkap (complete panel data) dan data panel tidak seimbang disebut juga data panel tidak lengkap (incomplete panel data) (Jacob, 2014).

Data panel memiliki beberapa keunggulan dibandingkan data time series dan data cross section, yaitu: 1) estimasi data panel dapat menunjukkan adanya heterogenitas dalam tiap unit, karena data panel berhubungan dengan setiap objek pada data cross section dari waktu ke waktu; 2) dengan menggabungkan data time series dan data cross section, data panel menjadi lebih informatif, memiliki tingkat kolinearitas antara peubah yang rendah, meningkatkan derajat kebebasan dan lebih efisien; 3) data panel cocok untuk menggambarkan adanya dinamika perubahan karena diamati secara berulang terhadap setiap objek cross section; 4) data panel mampu mendeteksi dan mengukur pengaruh yang tidak dapat diamati pada data time series atau data cross section; 5) data panel dapat digunakan untuk studi dengan model yang lebih lengkap (Jacob, 2014).

\subsection{Regresi Data Balanced Panel}

Ada beberapa model regresi panel, salah satunya adalah model dengan slope konstan dan intercept bervariasi. Model regresi panel yang hanya dipengaruhi oleh salah satu unit saja (unit cross-sectional atau unit waktu) disebut model komponen satu arah, sedangkan model regresi panel yang dipengaruhi oleh kedua unit (unit cross-sectional dan unit waktu) disebut model komponen dua arah. Secara umum terdapat dua pendekatan yang digunakan dalam menduga model dari data panel yaitu model tanpa pengaruh individu (common effect) dan model dengan pengaruh individu (fixed effect dan random effect) (Pangestika, 2015).

Menurut (Sunengsih, 2009), analisis regresi data panel adalah analisis regresi yang didasarkan pada data panel untuk mengamati hubungan antara satu peubah terikat (dependent variable) dengan satu atau lebih peubah bebas (independent variable). Beberapa alternatif model yang dapat diselesaikan dengan data panel yaitu, Model regresi data panel, baik data panel lengkap dan data panel tidak lengkap secara bersama dapat dinyatakan sebagai berikut:

$$
\begin{aligned}
& Y_{i t}=\alpha+\sum_{k-1}^{K} X_{i t k} \beta_{k}+\varepsilon_{i t} \\
& i=1, \ldots, \mathrm{N}, t=1, \ldots, t, \text { dan } k=1, \ldots, \mathrm{K}
\end{aligned}
$$

dengan $\mathrm{N}$ adalah banyaknya pengamatan objek; $\mathrm{t}$ adalah banyaknya waktu pengamatan; $\mathrm{N} \mathrm{x}$ t adalah banyaknya data panel; $Y_{i t}$ adalah nilai peubah responss untuk objek ke-i dan waktu ke-t; $X_{i t k}$ adalah koefisien intersep yang merupakan skalar; adalah pengamatan terhadap k peubah bebas untuk objek ke-i dan waktu ke-t; adalah koefisien regresi; $\beta_{k}$ adalah komponen galat pada model regresi data panel. Komponen galat $\varepsilon_{i t}$ pada model regresi data panel (2.3) dapat dibedakan berdasarkan pengaruh objek dan pengaruh waktu (Jacob, 2014), yaitu: 
a. Model regresi komponen galat satu arah

$\varepsilon_{i t}=\mu_{i}+v_{i t}$

b. Model regresi komponen galat dua arah

$\varepsilon_{i t}=\mu_{i}+\lambda_{t}+v_{i t}$

Diketahui $\mu_{i}$ merupakan pengaruh khusus objek ke- $i$ yang tidak teramati; $\lambda_{t}$ merupakan pengaruh yang tidak teramati pada waktu ke-t; dan $v_{i t}$ merupakan sisa galat yang benar benar tidak diketahui (remainder disturbance) pada objek ke- $i$ dan waktu ke- $t$.

Berdasarkan jenis komponen galat (Jacob, 2014), model regresi data panel dapat dibedakan sebagai berikut:

a. Model regresi data panel lengkap dengan komponen galat satu arah dan komponen galat dua arah secara bersama memiliki dimensi $\mathrm{Nt}$ dengan jumlah pengamatan objek dan waktu adalah $\mathrm{t}=1, \ldots, \mathrm{N}$ dan $\mathrm{t}=1, \ldots, \tau$.

b. Model regresi data panel tidak lengkap dengan komponen galat satu arah memiliki jumlah pengamatan objek $i=$ $1, \ldots, \mathrm{N}$ dan jumlah waktu yang berbeda pada setiap objek yang diamati $t=1, \ldots, \tau_{1}$. Sedangkan, model regresi komponen galat dua arah memiliki jumlah pengamatan waktu $t=1, \ldots, \tau$ dan jumlah objek berbeda yang diamati pada setiap periode waktu adalah $i=1, \ldots, N_{t}$.

\subsection{Uji Asumsi Model Regresi Data Panel}

Setiap metode statistika memiliki kelebihan dan kekurangan, memiliki karakteristik masing-masing, dan memiliki asumsi tersendiri yang tidak bisa dilanggar, dan akan berpengaruhi pada hasil analisis. Menurut (Ra'yan, 2018) ada beberapa asumsi yang harus diperhatikan pada analisis regresi data panel yaitu sebagai berikut:

a. Uji Normalitas

Data klasifikasi kontinu dan data kuantitatif yang termasuk dalam pengukuran data skala interval atau rasio agar dapat dilakukan uji statistik parametrik dipersyaratkan berdistribusi normal. Pembuktian data berdistribusi normal tersebut perlu dilakukan uji normalitas terhadap data. Uji normalitas berguna untuk membuktikan data dari sampel yang dimiliki berasal dari populasi berdistribusi normal atau data populasi yang dimiliki berdistribusi normal. Banyak cara yang dapat dilakukan untuk membuktikan suatu data berdistribusi normal atau tidak (Ra'yan, 2018)

b. Multikolinearitas

Apabila digunakan model regresi linear berganda $Y_{i}=\beta_{1}+\beta_{2} X_{2 i}+\beta_{3} X_{3 i}+\cdots+\beta_{k} X_{k i}+\varepsilon_{i}$, dalam hal ini asumsi bahwa $x_{1}, x_{2}, \ldots, x_{\mathrm{k}}$ sebagai peubah-peubah bebas tidak berkorelasi satu sama lain. Jika peubah-peubah bebas tersebut berkorelasi satu sama lain, maka dikatakan terjadi kolinearitas berganda (multi collinearity). Hal ini sering terjadi pada data berkala (time series data). Ada kemungkinan terdapat 2 peubah atau lebih yang mempunyai hubungan (korelasi) yang sangat kuat sehingga pengaruh masing-masing peubah tersebut terhadap y sulit untuk dibedakan (Ra'yan, 2018). Uji multikolinearitas biasanya dapat dilihat dari nilai VIF (Variance Inflation Factor) yang lebih dari 10.

c. Autokorelasi

Istilah autokorelasi dapat didefinisikan sebagai "korelasi antara anggota serangkaian observasi yang diurutkan menurut waktu (data time series) atau ruang (data cross-sectional)". Dalam konteks regresi, model regresi linear klasik mengasumsikan bahwa autokorelasi seperti itu tidak terdapat dalam gangguan $\left(\varepsilon_{\mathrm{i}}\right)$. Dengan menggunakan lambing (Ra'yan, 2018):

d. Heterokedastisitas

Untuk mengetahui apakah struktur variance-covariance residual bersifat homokedastik atau heterokedastik dapat digunakan uji Lagrange Multiplier (LM) dan uji breusch pagam (Ra’yan, 2018).

\subsection{Pendekatan Model Regresi Data Panel}

Model regresi data panel terbagi menjadi tiga pendekatan (Jacob, 2014) yaitu: common effect models, fixed effect models, dan random effect model. 


\section{a. Common effect models}

Pendekatan yang paling sederhana untuk mengestimasi model regresi data panel adalah melakukan penggabungan data time series dan cross section yang dikenal dengan metode pooled least square atau common effect models. Model pendekatan penggabungan semua data ditunjukkan pada model regresi data panel (2.3) dan dapat diestimasi menggunakan metode MKT dengan asumsi intersep $(\alpha)$ dan koefisien kemiringan $(\beta)$ konstan setiap waktu dan objek. Karena pendekatan ini menganggap semua objek sama atau homogen, maka perubahan antara objek tersebut akan sulit terlihat (Jacob, 2014). Secara umum, persamaan modelnya dituliskan sebagai berikut.

$$
Y_{i t}=\beta_{0}+\beta X_{i t}+\varepsilon_{i t}
$$

dengan:

$Y_{i t}=$ Peubah respon pada unit observasi ke-i dan waktu ke-t

$X_{i t}=$ Peubah prediktor pada unit observasi ke-i dan waktu ke-t

$\beta=$ Koefisien slope atau koefisien arah

$\beta_{0}=$ Intercept model regresi

$\varepsilon_{i t}=$ Galat atau komponen error pada unit observasi ke-i dan waktu ke-t

b. Fixed effect models

Data dengan asumsi intersep dan koefisien kemiringan konstan antara waktu dan objek, memungkinkan sebuah pendekatan lain dengan cara menambahkan peubah semu (dummy variable) ke dalam model sehingga parameter baik intersep dan koefisien kemiringan berbeda antara waktu dan objek. Pendekatan ini disebut model efek tetap atau fixed effect models (FEM) dengan model regresi diasumsikan mempunyai koefisien kemiringan konstan tetapi intersep berbeda pada setiap objek (Jacob, 2014), yaitu: .

$$
Y_{i t}=\beta_{0 i}+\sum_{k-1}^{K} X_{i t k} \beta_{k}+\varepsilon_{i t}
$$

Meskipun adanya asumsi intersep setiap objek berbeda yang ditandai dengan indeks i pada persamaan (2.7), tetapi tidak ada perbedaan pada setiap waktu. Perbedaan intersep disetiap objek bisa disebabkan karena ciri khusus setiap objek cross section, sehingga dapat menggunakan peubah semu untuk mengetahui besarnya perbedaan koefisien regresi tiap objek (Jacob, 2014).

\section{c. Random effect models}

Permasalahan yang ditimbulkan pada pendekatan FEM dapat diatasi dengan pendekatan random effect models (REM). Pada pendekatan ini, pemilihan objek dan waktu dilakukan secara acak (random) sehingga pengaruh (effects) dari objek dan waktu diasumsikan merupakan peubah acak. Dengan demikian, perbedaan karakteristik objek dan waktu pada REM dapat dilibatkan pada galat dari model (Jacob, 2014).

Berdasarkan model komponen galat satu arah (2.4) dan model komponen galat dua arah (2.5), terdapat komponen galat objek $\mu_{i} \sim \operatorname{IIDN}\left(0, \sigma_{\mu}^{2}\right)$ dengan asumsi, komponen galat waktu $\lambda_{i} \sim \operatorname{IIDN}\left(0, \sigma_{\mu}^{2}\right)$, dan sisa galat yang benar-benar tidak diketahui penyebabnya $v_{i} \sim \operatorname{IIDN}\left(0, \sigma_{\mu}^{2}\right)(\mathrm{Jacob}, 2014)$.

Menurut (Ra'yan, 2018) sebagaimana telah diketahui bahwa pada Fixed effect models (FEM), perbedaan karakteristik-karakteristik individu dan waktu diakomodasikan pada intercept sehingga intercept-nya berubah antar waktu. Sementara Random effect models (REM) perbedaan karakteristik individu dan waktu diakomodasikan pada error dari model. Mengingat ada dua komponen yang mempunyai kontribusi pada pembentukan error, yaitu individu dan waktu maka random error pada REM juga perlu diurai menjadi error untuk komponen waktu dan error gabungan. Dengan demikian persamaan REM diformulasikan sebagai berikut.

$$
Y_{n}=\beta_{0}+\beta X_{i t}+\varepsilon_{i t}: \quad \varepsilon_{i t}=u_{i}+v_{t}+w_{i t}
$$

dimana:

$u_{i}:$ Komponen error cross section

$v_{t}:$ Komponen error time series

$w_{i t}$ : Komponen error gabungan. 


\subsection{Pemilihan Model Estimasi Regresi Data Panel}

Terdapat 3 metode yang digunakan dalam pemilihan model estimasi regresi data panel (Pangestika, 2015):

a. Uji chow

Uji chow digunakan untuk melihat model yang terbaik antara common effect model dengan fixed effect model

b. Uji hausman

Uji hausman digunakan untuk melihat model terbaik antara random effect model dengan fixed effect model.

c. Uji breusch pagan

Uji breusch pagan digunakan untuk melihat efek waktu, individu, atau keduanya.

Hipotesis:

$\mathrm{H}_{\mathrm{o}}: \mathrm{c}=0, \mathrm{~d}=0$, atau tidak terdapat efek cross section dan waktu

$H_{0}^{c}: \mathrm{c}=0, \mathrm{~d}_{\mathrm{t}} \sim$ iid, $\mathrm{N}\left(0, \sigma_{d}^{2}\right)$ atau tidak terdapat efek cross section

$H_{1}^{c}: \mathrm{c} \neq 0, \mathrm{~d}_{\mathrm{t}} \sim$ iid, $\mathrm{N}\left(0, \sigma_{d}^{2}\right)$ atau terdapat efek cross section

$H_{0}^{d}: \mathrm{d}=0, \mathrm{c}_{\mathrm{i}} \sim$ iid, $\mathrm{N}\left(0, \sigma_{c}^{2}\right)$ atau tidak terdapat efek waktu

$H_{1}^{d}: \mathrm{d} \neq 0, \mathrm{c}_{\mathrm{i}} \sim$ iid, $\mathrm{N}\left(0, \sigma_{c}^{2}\right)$ atau terdapat efek waktu

\subsection{Angka Buta Huruf}

Angka Buta Huruf merupakan proporsi penduduk usia 15 tahun ke atas yang tidak mempunyai kemampuan membaca dan menulis, baik huruf latin maupun huruf lainnya, terhadap penduduk usia 15 tahun ke atas. Kemampuan membaca yang dimaksud di sini tidak dituntut harus bisa mengerti apa yang dibaca/ditulisnya. Manfaat angka ini adalah untuk melihat pencapaian indikator dasar yang telah dicapai oleh suatu daerah, karena membaca merupakan dasar utama dalam memperluas ilmu pengetahuan (Nusa Tenggara Barat dlam angka tahun 2017).

\section{Metode Penelitian}

\subsection{Sumber data}

Data yang digunakan adalah data sekunder yang diperoleh dari Badan Pusat Statistik (BPS) Provinsi Nusa Tenggara Barat dan instansi-instansi pemerintahan yang terkait. Data yang diambil dari BPS adalah data angka partisipasi murni tingkat SD, angka partisipasi murni tingkat SMP, angka partisipasi murni tingkat SMA, rasio murid-guru tingkat SD, rasio murid-guru tingkat SMP, rasio murid-guru tingkat SMA, persentase penduduk miskin dan melek huruf berdasarkan waktu.

\subsection{Definisi operasional peubah}

Adapun definisi dari peubah yang digunakan dalam penelitian ini adalah sebagai berikut:

a. Angka Partisipasi Murid Tingkat SD $\left(\mathrm{X}_{1}\right)$

Angka partisipasi murid tingkat SD digunakan untuk mengetahui partisipasi sekolah anak SD ditinjau dari ketepatan usia sekolah pada jenjang pendidikan SD. Tinggi rendahnya nilai APM ini lebih disebabkan oleh kesesuaian penduduk usia 7-12 tahun yang sedang duduk di SD.

b. Angka Partisipasi Murid Tingkat SMP $\left(\mathrm{X}_{2}\right)$

Angka partisipasi murid tingkat SMP digunakan untuk mengetahui partisipasi sekolah anak SMP ditinjau dari ketepatan usia sekolah pada jenjang pendidikan SMP.

c. Angka Partisipasi Murid Tingkat SMA $\left(\mathrm{X}_{3}\right)$ 
Angka partisipasi murid tingkat SMP digunakan untuk mengetahui partisipasi sekolah anak SMA ditinjau dari ketepatan usia sekolah pada jenjang pendidikan SMP.

d. Rasio Murid-Guru Tingkat SD $\left(\mathrm{X}_{4}\right)$

Rasio murid-guru ialah perbandingan antara jumlah murid SD terhadap jumlah guru SD pada jenjang pendidikan SD.

e. Rasio Murid-Guru Tingkat SMP $\left(\mathrm{X}_{5}\right)$

Rasio murid-guru ialah perbandingan antara jumlah murid SMP terhadap jumlah guru SMP pada jenjang pendidikan SMP.

f. Rasio Murid-Guru Tingkat SMA $\left(\mathrm{X}_{6}\right)$

Rasio murid-guru ialah perbandingan antara jumlah murid SMA terhadap jumlah guru SMA pada jenjang pendidikan SMA.

g. Persentase Penduduk Miskin $\left(\mathrm{X}_{7}\right)$

Penduduk miskin adalah penduduk yang memiliki rata-rata pengeluaran per kapita per bulan dibawah garis kemiskinan.

h. Melek huruf (Y)

Melek huruf adalah persentase penduduk 15 tahun ke atas yang mampu membaca dan menulis minimal kalimat sederhana yang digunakan dalam kehidupan sehari-hari.

\subsection{Teknik analisis}

Teknik atau metode analisis data dalam penelitian ini adalah sebagai berikut

a) Mendeskripsikan angka partisipasi murni tingkat SD, angka partisipasi murni tingkat SMP, angka partisipasi murni tingkat SMA, rasio murid-guru tingkat SD, rasio murid-guru tingkat SMP, rasio murid-guru tingkat SMA, persentase penduduk miskin, dan melek huruf Provinsi Nusa Tenggara Barat Tahun 2015-2018

b) Menentukan estimasi model regresi data panel yang terbaik dengan menggunakan uji chow, hausman, dan lagrange multipler.

c) Mengestimasi parameter dengan model regresi data panel yang terpilih random effect model, fixed effect model, dan common effect model.

d) Mendeteksi kenormalan galat, gejala heteroskedastisitas, multikolinearitas, dan autokorelasi dengan melakukan uji asumsi klasik.

e) Melakukan pengujian signifikansi parameter dengan menggunakan uji serentak F dan uji parsial t.

f) Balanced panel

g) Koefisien determinasi $\left(\mathrm{R}^{2}\right)$

h) Menguji Komponen galat dua arah

\section{Hasil dan Pembahasan}

\subsection{Menentukan Model Regresi Data Panel yang Terbaik}

Model regresi data panel ada tiga yaitu common effect model, fixed effect model, dan random effect model. Pemilihan model terbaik dari ketiga model regresi data panel menggunakan uji chow, uji hausman, dan uji breusch pagan. Uji breusch pagan bisa tidak digunakan karena pada uji chow dan uji hausman sudah ditentukan model yang terbaik. Adapun pemilihan model regresi data panel yang terbaik dengan menggunakan uji chow dan uji hausman adalah sebagai berikut (Pangestika, 2015): 
a. Uji Chow

Pengujian analisis uji chow dilakukan untuk melihat model yang terbaik antara common effect model dengan fixed effect model. Adapun hipotesis dari uji chow yaitu:

$\mathrm{H}_{\mathrm{o}}: \alpha_{1}=\alpha_{2}=\cdots=\alpha_{n}$ (efek unit cross section secara keseluruhan tidak berarti) common effect model

$\mathrm{H}_{1}$ : minimal ada satu $\alpha_{i} \neq 0 ; \mathrm{i}=1,2, \ldots, \mathrm{n}$ (efek wilayah berarti) fixed effect model

Uji chow menggunakan $\alpha=0,05$ dengan statistik ujinya yaitu:

Dimana

$$
F_{\text {hitung }}=\frac{\left(R S S_{1}-R S S_{2}\right) /(n-1)}{R S S_{2} /(n T-n-K)}
$$

$$
R S S=\sum_{i=1}^{n}\left(Y_{i t}-\left(\beta_{0 i t}+\beta_{1 i t}\right)\right)^{2}
$$

Adapun hasil uji chow untuk menentukan model yang terbaik antara common effect model dengan fixed effect model adalah sebagai berikut:

Tabel 1 Hasil Analisis Uji Chow

\begin{tabular}{cc}
\hline $\mathrm{F}$ & $P$-value \\
\hline 44,55 & $0,19 \times 10^{-11}$ \\
\hline
\end{tabular}

Dari Tabel 1 hasil analisis uji chow didapatkan nilai $p$-value yaitu $0,19 \times 10^{-11}$ yang lebih kecil dari $\alpha$ yaitu 0,05 . Hal ini berarti tolak Ho yang artinya terdapat efek individu sehingga fixed effect model lebih baik dari common effect model.

b. Uji Hausman

Pengujian analisis uji hausman dilakukan untuk melihat model yang terbaik antara random effect model dengan fixed effect model. Adapun hipotesis dari uji hausman adalah sebagai berikut:

$\mathrm{H}_{\mathrm{o}}$ : korelasi $\left(X_{i t}, \varepsilon_{i t}\right)=0$ (efek cross-sectional tidak berhubungan dengan regresor lain) random effect model

$\mathrm{H}_{1}$ : korelasi $\left(X_{i t}, \varepsilon_{i t}\right) \neq 0$ (efek cross-sectional berhubungan dengan regresor lain) fixed effect model

Uji hausman menggunakan $\alpha=0,05$, dan tolak H0 jika w $>\chi^{2}$ dengan statistik ujinya yaitu:

Dimana

$$
w=\hat{q} \operatorname{Var}(\hat{q})^{-1} \hat{q}
$$

$$
\hat{q}=\left[\hat{\beta}_{0}-\hat{\beta}_{0 G L S}\right] \operatorname{dan} \operatorname{var}(\hat{q})=\operatorname{Var}\left(\hat{\beta}_{0}\right)-\operatorname{Var}\left(\hat{\beta}_{0 G L S}\right)
$$

Adapun hasil uji hausman untuk menentukan model terbaik antara random effect model dengan fixed effect model adalah sebagai berikut:

Tabel 2 Hasil Analisis Uji Hausman

\begin{tabular}{cc}
\hline Chi-square & $P$-value \\
\hline 0,618 & 0,998 \\
\hline
\end{tabular}

Dari Tabel 2 hasil analisis uji hausman didapatkan nilai $p$-value yaitu 0,998 yang lebih besar dari $\alpha$ yaitu 0,05 . Hal ini berarti gagal tolak Ho yang artinya efek cross sectional berhubungan dengan regresor lain sehingga random effect model lebih baik dari fixed effect model.

\subsection{Mengestimasi Parameter dengan Model Regresi Data Panel yang Terbaik}

Ada tiga model yang digunakan untuk mengestimasi parameter dalam regresi data panel yaitu common effect model, fixed effect model, dan random effect model. Setelah dilakukan uji model regresi data panel yang terbaik dengan uji chow dan uji hausman didapatkan model regresi data panel yang terbaik adalah Random effect model. 
Adapun hipotesis dari estimasi parameter menggunakan random effect model yaitu

Ho : $\hat{\beta}_{j}=0 ; j=1,2,3,4,5,6,7$

$\mathrm{H}_{1}: \hat{\beta}_{j} \neq 0 ; \quad \mathrm{j}=1,2,3,4,5,6,7$

Uji random effect menggunakan $\alpha=0,05$ dengan statistik ujinya yaitu:

$$
t_{\text {hitung }}=\frac{\hat{\beta}_{j}}{\operatorname{se}\left(\hat{\beta}_{j}\right)}
$$

Hasil estimasi parameter dengan random effect model (lampiran 6) disajikan pada Tabel 3.

Tabel 3 Hasil Analisis Random Effect Models

\begin{tabular}{ccccc}
\hline Peubah & Koefisien & Standar Error & t-value & $P$-value \\
\hline Intersept & 117,5728 & 13,8590 & 8,4835 & $0,22 \times 10^{-15}$ \\
X1 & $-0,2710$ & 0,1503 & $-1,8016$ & 0,0716 \\
X2 & $-0,0204$ & 0,0525 & $-0,3875$ & 0,6984 \\
X3 & 0,0639 & 0,0717 & 0,8901 & 0,3734 \\
X4 & $-0,0484$ & 0,0602 & $-0,8039$ & 0,4215 \\
X5 & $-0,1967$ & 0,0825 & $-2,3826$ & 0,0172 \\
X6 & 0,3091 & 0,1090 & 2,8337 & 0,0046 \\
X7 & $-0,3297$ & 0,1515 & $-2,1761$ & 0,0296 \\
\hline
\end{tabular}

Pada Tabel 3 terdapat terdapat 4 peubah yaitu peubah X1 (angka partisipasi murni SD), X2 (angka partisipasi murni SMP), X3 (angka partisipasi murni SMA), dan X4 (rasio murid guru SD) yang tidak signifikan dalam model karena p-value lebih besar dari $\alpha=0,05$, sehingga peubah tersebut dikeluarkan. Langkah selanjutnya adalah menganalisis peubah yang signifikan dalam model. Hasil estimasi parameter dengan random effect model dengan peubah yang signifikan dapat dilihat pada Tabel 4.

Tabel 4 Hasil Analisis Random Effect Models Yang Signifikan

\begin{tabular}{ccccc}
\hline Peubah & Koefisien & Standar Error & $t$-value & $P$-value \\
\hline Intersept & 90.0766 & 3.0645 & 29.3933 & $2.2 \times 10^{-16}$ \\
X5 & -0.2442 & 0.0701 & -3.4826 & 0.0005 \\
X6 & 0.3167 & 0.0899 & 3.5216 & 0.0004 \\
X7 & -0.1410 & 0.1453 & -0.9700 & 0.3320 \\
\hline
\end{tabular}

Dari tabel 4, hasil Analisis Random Effect Models Yang Signifikan, didapatkan peubah yang tidak signifikan dalam model yaitu peubah X7 (persentase penduduk miskin) sehingga peubah X7 harus dikeluarkan dan dianalisis kembali peubah X5 dan X6 yang signifikan dalam model. Hasil estimasi parameter dengan random effect model dengan peubah X5 dan X6 yang signifikan disajikan pada tabel 5. 
Tabel 5 Hasil Analisis Random Effect Models X5 dan X6 Yang Signifikan

\begin{tabular}{ccccc}
\hline Peubah & Koefisien & Standar Error & t-value & $P$-value \\
\hline Intersept & 87.6534 & 1.8245 & 48.0428 & $2.2 \times 10^{-16}$ \\
X5 & -0.2690 & 0.0644 & -4.1756 & $2.972 \times 10^{-05}$ \\
X6 & 0.3501 & 0.0821 & 4.2659 & $1.991 \times 10^{-05}$ \\
\hline
\end{tabular}

Berdasarkan Tabel 5 hasil analisis random effect models X5 dan X6 yang signifikan dibentuk model regresi sebagai berikut:

$$
\hat{Y}=87,6534-0,2690 \mathrm{X}_{5}+0,3501 \mathrm{X}_{6}+\varepsilon
$$

\subsection{Asumsi Regresi Data Panel}

Ada beberapa asumsi yang harus dipenuhi dalam melakukan analisis regresi data panel yaitu:

a. Normalitas

Uji normalitas membuktikan data dari sampel yang dimiliki berasal dari populasi berdistribusi normal atau data populasi yang dimiliki berdistribusi normal. uji yang digunakan untuk menentukan normalitas data adalah uji Kolmogorov smirnov dengan hipotesis sebagai berikut:

H0 : residual berdistribusi normal

$\mathrm{H} 1$ : residual tidak berdistribusi normal

Uji normalitas menggunakan $\alpha=0,05$ dengan statistik ujinya yaitu:

$$
|F t-F s|
$$

Adapun hasil dari uji Kolmogorov smirnov adalah sebagai berikut:

Tabel 6 Hasil Analisis Uji Kolmogorov Smirnov

\begin{tabular}{cc}
\hline Kolmogorov Smirnov & $P$-value \\
\hline 0,1248 & 0,1206 \\
\hline
\end{tabular}

Dari Tabel 6, hasil Analisis Uji Kolmogorov Smirnov didapatkan nilai p-value $(0,1206)$ lebih besar dari $\alpha$ $(0,05)$, hal ini berarti gagal tolak Ho yang artinya data berdistribusi normal.

b. Multikolinearitas

Multikolinearitas digunakan untuk melihat apakah terdapat hubungan antara peubah bebas. Kriteria untuk melihat multikolinearitas adalah jika nilai VIF (Variance Inflation Factor) lebih dari 10 maka terjadi multikolinearitas.

Tabel 7 Hasil Analisis Uji Multikolinearitas

\begin{tabular}{cc}
\hline Peubah & VIF \\
\hline X1 & 1,7344 \\
X2 & 1,8526 \\
X3 & 1,8819 \\
X4 & 3,2460 \\
X5 & 4,5831 \\
X6 & 4,9100 \\
X7 & 1,3616 \\
\hline
\end{tabular}


Pada Tabel 7 Hasil Analisis Uji Multikolinearitas didapatkan nilai VIF peubah dapat dilihat bahwa tidak ada nilai VIF peubah bebas (X1 (angka partisipasi murni tingkat SD), peubah X2 (angka partisipasi murni tingkat SMP), peubah X3 (angka partisipasi murni tingkat SMA), peubah X4 (rasio murid guru tingkat SD), peubah X5 (rasio murid guru tingkat SMP), peubah X6 (rasio murid guru tingkat SMA), dan peubah X7 (persentase penduduk miskin)) tidak ada yang lebih dari 10, yang artinya tidak ada multikolinearitas antara peubah bebas.

c. Autokorelasi

Uji autokorelasi digunakan untuk melihat korelasi antara anggota serangkaian observasi yang diurutkan menurut waktu, pengujian autokorelasi menggunakan uji Durbin Watson dengan hipotesis sebagai berikut:

H0 : tidak terdapat autokorelasi

$\mathrm{H} 1$ : terdapat autokorelasi

Uji autokorelasi menggunakan $\alpha=0,05$ dengan statistik ujinya adalah sebagai berikut:

$$
d=\frac{\sum_{i-2}^{N}\left(e_{i}-e_{i-1}\right)^{2}}{\sum_{i-1}^{N} e_{i}^{2}}
$$

Hasil uji autokorelasi dengan menggunakan uji durbin watson adalah sebagai berikut:

Tabel 8 Hasil Analisis Uji Durbin Watson

\begin{tabular}{cc}
\hline Durbin Watson & $P$-value \\
\hline 1,494 & 0,069 \\
\hline
\end{tabular}

Pada Tabel 8, hasil Analisis Uji Durbin Watson didapatkan nilai durbin Watson 1,494 dengan p-value 0,069 yang lebih besar dari $\alpha(0,05)$. Hal ini berarti gagal tolak Ho yang artinya tidak terjadi autokorelasi.

d. Heterokedastisitas

Uji heterokedastisitas digunakan untuk mengetahui apakah struktur variance-covariance residual bersifat homokedastisitas atau heterokedastisitas, uji yang digunakan adalah uji bresusch pagan dengan hipotesis sebagai berikut:

H0 : $\sigma_{i}^{2}=\sigma^{2}$ (variansi error tetap atau homoskedastisitas)

H1 : minimal ada satu $\sigma_{i}^{2} \neq \sigma^{2}$ (variansi error berubah-ubah atau heteroskedastisitas); i=1,2,..,N

Uji heterokedastisitas menggunakan $\alpha=0,05$ dengan uji statistik yaitu:

$$
B P=(0,5 x S S E) /(J K G / n)^{2}
$$

Adapun hasil uji breusch pagan yaitu sebagai berikut:

Tabel 9 Hasil Analisis Uji Breusch Pagan

\begin{tabular}{cc}
\hline Breusch pagan & $p$-value \\
\hline 8,6909 & 0,27 \\
\hline
\end{tabular}

Pada Tabel 9, hasil Analisis Uji Durbin Watson didapatkan nilai breusch pagan sebesar 8,6909 dengan p-value sebesar 0,27 yang lebih besar dari $\alpha(0,05)$. Hal ini berarti gagal tolak Ho yang artinya tidak terjadi heterokedastisitas

\subsection{Balanced Panel}

Berdasarkan kelengkapan data panel, terdapat dua jenis data panel yaitu data panel seimbang (balanced panel data) dan data panel tidak seimbang (unbalanced panel data). Jika setiap objek memiliki jumlah pengamatan waktu yang sama maka data panel disebut data panel seimbang. Sedangkan jika jumlah pengamatan waktu berbeda pada setiap objek, maka data panel disebut data panel tidak seimbang (Jacob, 2014). 
Tabel 10 Hasil Balanced Panel

\begin{tabular}{ccc}
\hline Individu & Waktu & Data panel \\
\hline 10 & 4 & 40 \\
\hline
\end{tabular}

Pada Tabel 10, hasil balanced panel didapatkan nilai individu sebesar 10 yang merupakan jumlah individu yaitu Lombok Barat, Lombok Tengah, Lombok Timur, Sumbawa, Dompu, Bima, Sumbawa Barat, Lombok Utara, Kota Mataram, dan Kota Bima. Selanjutnya Pada Tabel 4.22 hasil balanced panel didapatkan nilai waktu sebesar 4 yang merupakan jumlah waktu yang digunakan yaitu Tahun 2015-2018, sehingga data yang digunakan sebanyak 40.

\subsection{Galat dua arah}

Komponen galat $\varepsilon_{i t}$ pada model regresi data panel (2.3) dapat dibedakan berdasarkan pengaruh objek dan pengaruh waktu (Jacob, 2014), galat yang terdapat pada model terbaik random effect model yaitu:

Tabel 11 Hasil Residual Random Effect Model

\begin{tabular}{ccc}
\hline Minimal & Median & Maksimal \\
\hline$-2,637$ & 0,104 & 1,648 \\
\hline
\end{tabular}

Dari Tabel 11, hasil residual random effect model didapatkan nilai residual terkecil -2,637 dan nilai residual terbesar adalah 1,648. Berdasarkan nilai residual tersebut didapatkan nilai galat objek ke- $i$ yang tidak teramati sebesar 1,00. Sedangkan galat pada waktu ke- $t$ yang tidak teramati sebesar $0,714 \times 10^{-14}$.

\section{Kesimpulan}

Dari hasil analisis dan pembahasan yang telah dijelaskan pada BAB sebelumnya, dapat diambil beberapa kesimpulan sebagai berikut:

1. Pada hasil uji parsial t, uji signifikansi masing-masing peubah bebas terhadap peubah terikat didapatkan beberapa peubah yang tidak signifikan terhadap peubah terikat yaitu: peubah angka partisipasi murni tingkat SD, angka partisipasi murni tingkat SMP, angka partisipasi murni tingkat SMA, dan rasio murid guru tingkat SD. Peubah yang signifikan yaitu rasio murid guru tingkat SMP rasio murid guru tingkat SMA, dan persentase penduduk miskin.

2. Dari hasil pemilihan model terbaik didapatkan model yang terbaik adalah model random effect, dengan uji asumsi klasik yang terpenuhi semua data berdistribusi normal, tidak terjadi multikolinearitas, tidak ada autokorelasi, dan tidak ada gejala heterokedastisitas. Model random effect yang terbentuk adalah sebagai berikut:

$$
\hat{Y}=87,6534-0,2690 \mathrm{X}_{5}+0,3501 \mathrm{X}_{6}+\varepsilon
$$

\section{References}

Astuti, N. K. (2017). Pemodelan Angka Buta Huruf di Kabupaten/Kota se-Jawa Timur dengan Metode Geographically Weighted t Regression. JURNAL SAINS DAN SENI ITS, 10.

Baltagi, B. H. (2005). Econometric Analysis of Panel Data. In John Wiley and Sons (Vol. 1). England.

Jacob, C. A. (2014). Analisis Model Regresi Data Panel Tidak Lengkap Komponen Galat Dua Arah dengan Penduga Feasible Generalized Least Square (FGLS). Jurnal Matematika, 17.

Minanews. (2019, November 28). 2,07 Persen Penduduk Indonesia Buta Aksara. Retrieved from https://minanews.net: https://minanews.net/tahun-2017-207-persen-penduduk-indonesia-buta-aksara/

NTB, B. (2018). Statistik Pendidikan Provinsi Nusa Tenggara Barat 2017. Mataram: BPS NTB.

NTB, B. (2019). Statistik Pendidikan Provinsi Nusa Tenggara Barat 2018. Mataram: BPS NTB.

Pangestika, S. (2015). "Analisis Estimasi Model Regresi Data Panel Dengan Pendekatan Common Effect Model (CEM), Fixed Effect Model (FEM), dan Random Effect Model (REM).” Unnes Journal, 2(1), 106.

Ra'yan, I. (2018). Analisis Regresi Data Panel Faktor-Faktor Yang Mempengaruhi Tingkat Kemiskinan Provinsi Sulawesi Selatan Tahun 2011-2015. Skripsi, 172. 
Simarmata, J. K. (2013, 11 30). KESALAHAN DALAM PENGGUNAAN ANALISIS REGRESI LINEAR OLEH MAHASISWA TINGKAT AKHIR. Retrieved from Mataraja Statistics Consultant: https://matarajastatistik.wordpress.com/2013/11/30/3/

Statistik, B. P. (2019). Statistik Pendidikan Provinsi NTB 2018. In Badan Pusat Statistik (Vol. 1). Mataram

Sunengsih, I. G. (2009). Kajian Analisis Regresi dengan Data Panel. Skripsi, 8.

Suntono. (2019). Indikator Strategis Statistik Sosial. Badan Pusat Statistik NTB.

Tiro, M. A. (2000). Analisis Korelasi dan regresi. Makassar: Andira Publisher.

Wooldridge, J. M. (2003). Econometric Analysis of Cross Section and Panel Data. In The MIT Press (Vol. 16). https://doi.org/10.1515/humr.2003.021 